\title{
ON EXPONENTIAL CONVEXITY, JENSEN-STEFFENSEN-BOAS INEQUALITY, AND CAUCHY'S MEANS FOR SUPERQUADRATIC FUNCTIONS
}

\author{
S. Abramovich, G. FARid, S. IVElić AND J. PeČARIĆ
}

\begin{abstract}
In this paper we define new means of Cauchy's type using some recently obtained results that refine the Jensen-Steffensen-Boas inequality for convex and superquadratic functions [4],[5]. Applying so called exp-convex method established in [8],[9], we interpret results in the form of exponentially convex or (as a special case) logarithmically convex functions. We also present some related results which generalize results in [2].
\end{abstract}

Mathematics subject classification (2010): 26D15.

Keywords and phrases: Jensen-Steffensen inequality, superquadratic functions, Cauchy Means, Monotonicity, exponential convexity, log-convexity.

\section{REFERENCES}

[1] S. Abramovich, S. BAnić, M. Matić And J. PeČARIĆ, Jensen-Steffensen's and related inequalities for superquadratic functions, Math. Ineqal. Appl. 11, 1 (2008), 23-41.

[2] S. Abramovich, G. FARID AND J. PeČArić, More about Hermite-Hadamard inequalities, Cauchy's mean and superquadracity, J. Ineqal. Appl., Volume 2010 (2010), Article ID 102467.

[3] S. Abramovich, G. FARID AND J. PeČARIĆ, More about Jensen's inequality and Cauchy's means for superquadratic functions, submitted.

[4] S. AbRamovich, S. IVElić AND J. PEČARIĆ, Improvement of Jenesen-Steffensen's Inequality for Superquadratic Functions, Banach J. Math. Anal. 4, 1 (2010), 159-169.

[5] S. Abramovich, S. Ivelić And J. PeČArić, Generalizations of Jenesen-Steffensen and related integral Inequalities for Superquadratic Functions, Cent. Eur. J. of Math. 8, 5 (2010), 937-949.

[6] S. Abramovich, G. Jameson and G. Sinnamon, Refining Jensen's Inequality, Bull. Math.Sic. Marh.Roum. 47 (2004), 3-14.

[7] S. Abramovich, M. Klaričić Bakula And S. Banić, A variant of Jensen-Steffensen's inequality for convex and superquadratic functions, J. Inequal. Pure Appl. Math. 7, 2 (2006), Art. 70.

[8] M. Anwar, J. Jakšetić J. PeČarić and AtiQ ur Rehman, Exponential Convexity, Positive Semi-Definite Matrices and Fundamental Inequalities, J. Math. Inequal. 4, 2 (2010), 171-189.

[9] M. ANWAR, J. PEČARIĆ, On logarithmic convexity for differences of power means and related results, Math. Ineqal. Appl. 12, 1 (2009), 81-90.

[10] S. BANIĆ, J. PEČARIĆ AND S. VAROŠANEC, Superquadratic functions and refinements of some classical inequalities, J. Korean Math. Soc. 45 (2008), 513-525.

[11] R. P. BoAs, The Jensen-Steffensen inequality, Univ. Beograd. Publ. Elektrotehn. Fak. Ser. Mat. Fiz. No. 302-319 (1970), 1-8.

[12] J. E. Pečarić, F. Proschan, Y. L. Tong, Convex Functions, Partial Orderings, and Statistical Applications, Academic Press, New York, 1992. 